AgnieszKa Gicala

Uniwersytet Jagielloński

\title{
Translations as Icebergs, Translators as Navigators: a Poetic Case Study
}

\section{Introduction}

To quote Michael Agar, "Culture becomes visible only when differences appear with reference to a newcomer, an outsider who comes into contact with it" (Agar 5). What this statement brings to mind are cultural problems found in translation. As an activity aimed at newcomers and outsiders, translation may constitute an excellent tool to study cultures. The question that I would like to ask is whether it is possible to uncover cultural differences, and with them, culture-bound linguistic worldviews, via a study of a single poem and its translation choices available in the target language. This study is an attempt to answer the above question via an analysis of English translations of Wisława Szymborska's poem Rozmowa $z$ kamieniem with its keyword kamien and its underlying cultural-linguistic foundations. The study is supported by the concept of linguistic worldview and, following the iceberg model of culture, offers a view of a poetic text and its translations as the tips of cultural-linguistic icebergs, which assigns to the translator the task of navigating the meanders of the source and target languages as well as diving below the surface of words.

\section{Cultural-linguistic icebergs, worldviews, and translation}

The model of culture as an iceberg, proposed by the American anthropologist Edward T. Hall (cf. e.g. Hall 1959), bases on the fact that what is visible in an iceberg is just its tiny tip while its vast main body is hidden under the water. Such 
a metaphor allows for making an important distinction between the "visible" and "invisible" elements of a culture and encourages further elaboration of the relations between its three parts. The levels are situated as follows: above the water level (visible, including art, food, drink, institutions, visible behaviours, etc., and most importantly: language and its products: texts), just below the water level (semi-visible, including customs and traditions, norms of appropriacy in dress, behaviour, etc.) and deep underwater (i.e. invisible, including mentalities, identities, beliefs and - most importantly - values).

For the translator, the value of this model lies in increased awareness of the fact that the invisible "underwater" part of a given culture poses a hidden danger of "crashing" against people's mentalities and beliefs. The metaphor facilitates our insight into the fact that the deeper down we "dive", the more unquestioned the components of a culture we might find; therefore, the less we are able to (metaphorically) see, i.e. to understand. Consequently, the more effort we need to make in order to avoid the risk of misunderstanding and ignorance. These strengths of the cultural iceberg have been used by David Katan (78-86), who applies the model for translators as intercultural communicators, explaining that in the top culture level:

The focus is on the text, dressed (adapting Newmark) in its best civilized clothes of a particular culture. At this 'technical' level the language signs have a clear WYsIWYG (what you see is what you get) referential function, and any associated hidden values are universal. The task of the translator at this level is to transfer the terms and concepts in the source text abroad with minimum loss [...] so that 'what you get' in the source text is equivalent to 'what you get' in the target text. (Katan 79)

What, however, Katan warns against is inter alia some culture-bound terms, such as culturemes, i.e. "formalized, socially and juridically embedded phenomena that exist in a particular form or function in only one of the two cultures being compared," demanding from the translator the application of either exoticising or assimilative procedures. Katan's examples of such "local colour" include "falafel, macho, Weltanschauung, burka" (Katan 80).

What applies at the second level are normality and appropriacy standards, which frequently do not translate into individual word choices but, rather, require manipulation (or: mediation), such as e.g. text form adjustment as related to text function with regard to what is acceptable in the target culture.

The third, "deepest" culture level is described by Hall as "out-of-awareness" or "unquestioned", hence it "both guides and constrains an individual's orien- 
tation in the real world" (Katan 84 ) by involving ethical values. Therefore, at this level, it is values and stereotypes as part of particular value systems that the translator ought to recognise and rethink, allowing target readers to experience a reasonable dose of text foreignness "from the safety of their own environmental bubble" (Katan 85) and thus learn something new in a safe way:

At this level of culture, no word is entirely denotative. Hence, even seemingly technical words can have 'cultural baggage' attached to them according to readership. Bassnett (1980/2002: 18-19, 28-9), for example, notes how global products, such as butter, whisky and Martini, can change status and connotation once translated or transferred to a new readership, due to culture-bound practice differences (Katan 85).

It is at this point that differences rooted in value systems and models of the world come to light and require the translator's decision (which in practice means: intervention). This occurs not only in the case of value labels, or keywords of a given culture (cf. Wierzbicka 1997), such as freedom or homeland, but seemingly non-problematic words, such as, to quote Katan, "the humble chrysanthemum, [which] has little specific connotation within the Anglo cultures, but strong symbolic meaning in most of the rest of the world. It is often the "flower of the dead" (Katan 85).

In this light, translation turns out to be an act of navigating the dangerous waters between as many as two cultural icebergs: the source and the target one. Also, performed in this light, the following study of a keyword in a Polish poem and its English translations may prove to be culturally relevant even if it has a "down-to-earth" denotation.

What remains to be defined is the concept of linguistic worldview, due to its compatibility with the cultural iceberg model, its relevance for translation as well as its tangible methodology. While the concept of linguistic worldview may be traced back to Aristotle, it is mainly ascribed to the thought of the German philosopher Wilhelm von Humboldt and the two American anthropologists: Edward Sapir and Benjamin Whorf. It is now being studied in different academic centres in Poland, among them the Lublin school of ethnolinguistics ${ }^{1}$. Its founder Jerzy Bartmiński defines linguistic worldview (in Polish: językowy obraz świata) as 'the interpretation of reality encoded in a given language" (Bartmiński 76)

1 Various approaches to the concept of linguistic worldview may be found in the collection of essays edited by Adam Głaz, David S. Danaher and Przemysław Łozowski (2013). 
and points to its presence at different levels of a language: lexical, grammatical, textual as well as pragmatic, which he calls 'co-linguistic' (referring to all linguistically relevant cultural data). Among the examples provided by Bartmiński to illustrate this definition are names of seemingly simple elements of reality that, apparently, are familiar to everybody. According to Bartmiński:

A worldview is an interpretation or projection, rather than a reflection of reality. Słońce 'sun', księżyc 'moon', woda 'water', wiatr 'wind' and ziemia 'earth', ręka 'hand, arm', oko 'eye', serce 'heart', nerki 'kidneys', kakol 'corn cockle', bławatek 'cornflower' or pies 'dog' are not mere labels denoting objectively existing things but expressions of definite semantic content (connotation), based on the segmentation and categorisation of phenomena performed by the human mind. Words 'portray' things mentally, rather than reproducing them in a photographic manner. (Bartmiński 76)

The analysis below attempts to show that Polish kamien' 'stone, rock' is one of such "mental portraits" of reality ${ }^{2}$.

\section{The two icebergs: Wisława Szymborska's Rozmowa z kamieniem and its English translations}

Published in 1962, Wisława Szymborska's poem Rozmowa z kamieniem appeared as the last poem in the volume Sól ('Salt') The poem has been translated into English twice, under two different titles: by Stanisław Barańczak and Clare Cavanagh (Szymborska 1997) as Conversation with a Stone, and by Joanna Trzeciak (Szymborska 2002[2001]) as Conversation with a Rock ${ }^{3}$. Scholars consider this poem as one of the more significant in Szymborska's output. To mention but a few examples, Stanisław Balbus regards Rozmowa z kamieniem as its author's "poetic declaration" (Balbus 1996); Marian Stala points to it as an expression of the poet's worldview, in which interaction between the human being and the world is in principle impossible (Stala 1996); this human alienation from the

2 Kamien is among the basic elements of reality mentioned by Wisława Szymborska in her lecture on receiving the Nobel Prize in Literature in 1996 (cf. Szymborska 1996).

3 To the best of my knowledge, these are the only published English translations of this poem. A complete, detailed list of all English translations of Szymborska's poetry (including the titles of individual poems and the work of all of her translators) can be found in Agata Brajerska-Mazur (320-329). 
world is also noted by Tadeusz Nyczek (2015); a less pessimistic interpretation is offered by Iwona Gralewicz-Wolny (2014). It is worth mentioning that the poem in question was published shortly after the appearance of another famous Polish poem about a stone, namely Zbigniew Herbert's Kamyk (translated into English by Czesław Miłosz as The Stone, and later The Pebble), thus a thread of intertextuality may be traced between the two texts.

The reader of Rozmowa $z$ kamieniem has their attention immediately drawn to the unusual protagonist: kamien' ('a stone/a rock') because it appears as early as the poem's title. By playing the role of the text's representative, its title serves the function of the first contact between the reader and the text, possibly manipulating the reader's further focus. The importance of attention in an experience of reading is pointed to by Peter Stockwell, who describes it from the cognitive-linguistic perspective in terms of figure and ground:

The most obvious correspondence of the phenomenon of figure and ground is in the literary critical notion of foregrounding. Certain aspects of literary texts are commonly seen as more important or salient than others. Though this is partly a subjective matter, it is also largely a matter of the cues that the text provides. [...]

Foregrounding within a text can be achieved by a variety of devices, such as repetition, unusual naming, innovative descriptions, creative syntactic ordering, puns, rhyme, alliteration, metrical emphasis, the use of creative metaphor, and so on. All of these can be seen as deviations from the expected or ordinary use of language that draw attention to an element, foregrounding it against the relief of the rest of the features of the text (Stockwell 14).

Among these devices is the topic of a text, expressed by the title, as done by Szymborska in the analysed poem. Not only does the word kamien (a stone/a rock) appear in the poem's title but it also assumes the role of an interlocutor in a conversation, which is atypical of inanimate objects. Stockwell comments on this kind of literary measure by using the term 'defamiliarisation':

More generally, the literary innovations and creative expression can be seen as foregrounding against the background of everyday non-literary language. In this view, one of the main functions of literature is to defamiliarise the subject-matter, to estrange the reader from aspects of the world in order to present the world in a creative and newly figured way (Stockwell 14). 
Having said that, let us now analyse closely the poem's main figure: kamień as an effect of defamiliarisation despite the fact that the poem is written in everyday language, and let us treat the lexeme in question as the poem's keyword. Secondly, let us look at what happens to kamien in each of the two English translations. The analyses of all three lexemes (kamień, stone and rock) are based on the above-mentioned assumption grounded in the iceberg model of culture, namely that single words are tips of cultural-linguistic icebergs and, at the same time, components of worldviews embedded in languages ${ }^{4}$. Quoted below is the first part of this long poem, chosen so as to highlight the key linguistic signals of the nature of kamień in this text.

\section{Rozmowa z kamieniem}

Pukam do drzwi kamienia.

- To ja, wpuść mnie.

Chcę wejść do twego wnętrza,

rozejrzeć się dokoła,

nabrać ciebie jak tchu.

- Odejdź - mówi kamień. -

Jestem szczelnie zamknięty.

Nawet rozbite na części

będziemy szczelnie zamknięte.

Nawet starte na piasek

nie wpuścimy nikogo.

Pukam do drzwi kamienia.

- To ja, wpuść mnie.

Przychodzę z ciekawości czystej.

Życie jest dla niej jedyną okazją.

Zamierzam przejść się po twoim pałacu,

a potem jeszcze zwiedzić liść i kroplę wody.

Niewiele czasu na to wszystko mam.

Moja śmiertelność powinna Cię wzruszyć.

4 A more detailed analysis of this poem as well as its published and non-professional English translations, incorporating a much broader study of the key lexemes in question, can be found in my book (Gicala 81-141). 
- Jestem z kamienia - mówi kamień -

i z konieczności muszę zachować powagę.

Odejdź stąd.

Nie mam mięśni śmiechu.

$[\ldots]$

The poem is constructed as a conversation, or rather a series of the poet's attempts at a conversation with kamień. The main conceptualisation of kamień is that of a living creature capable of a meaningful verbal interaction, the poet's interlocutor; however, one that consistently refuses the poet's requests for contact and closer acquaintance. In the end, the poet receives the final refusal and is left with a sad awareness that the human world is totally incompatible with that of kamień.

As pointed out by Anna Pajdzińska in her analysis of Szymborska’s poem in question (Pajdzińska 48-51), the connotations of the Polish lexeme kamien are mostly negative (cf. also my analysis in Gicala 83-95). Among other meanings, the lexeme appears in idioms referring to a person's unwillingness or incapability of verbal or emotional response, i.e. either complete silence (milczeć jak kamień [literally: 'to be silent as a stone'], kamienne milczenie ['stony silence']) or insensitivity, even cruelty (kamień, nie człowiek ['a stone, not a human being'], mieć serce $z$ kamienia ['to have a heart of stone'], być $z$ kamienia ['to be made of stone']). It must be admitted that, in accordance with various co-linguistic data, the rich symbolic meanings and functions of stones and rocks do not absolutely exclude the possibility of contact: stones and rocks have been believed to provide access to the supernatural, to "the other world", and to have magical powers (e.g. various stone circles, birthstones, amulets - cf. Kopaliński 139) The idiom być $z$ kamienia ['to be made of stone'] is present in Szymborska's poem in an unusual, 1st person form: ,jestem $z$ kamienia” (literally: 'I am [made]

5 Interestingly, Władysław Kopaliński’s dictionary of symbols in cultures (Kopaliński 1990), written in Polish, mentions stones and rocks (Polish kamienie and skały) together, in a single entry. Thus, evidently, they share symbolic meanings despite the fact that in the Polish language there are two lexemes: kamien and skała. While the former has mostly negative connotations in its metaphorical meanings, the axiology of idioms containing the Polish word skała is not so univocal. Negatively charged idioms include twardy jak skała 'hard as a rock' (i.e. insensitive, cruel) or zamienić się w skałę (literally 'to change into a rock', i.e. to become insensitive). Among the positively charged are ones rooted in the Bible: być jak skała (literally 'to be like a rock') and być [czyjąś] skała (literally 'to be someone's rock'). The meaning of both is 'to be someone's support', 'to be a person that someone else can trust absolutely. 
of stone/rock'), which kamień further explains, adding „i z konieczności muszę zachować powagę" ('and out of necessity I must be serious'). In the poem, the Polish idiom być z kamienia is very subtly used - in its metaphorical and literal meaning at the same time - by kamień itself in order to reveal its true nature and in this way support its argumentation against any acquaintance with the human being.

Following the above-mentioned study by Anna Pajdzińska, it can be said that our understanding of Szymborska's poem depends very largely on treating the word kamien as the poem's keyword and on incorporating the broader linguistic and 'co-linguistic' (cultural) worldview, related to this word, in interpretation of this text. Pajdzińska links this fact to the broader phenomenon of anthropocentrism (Pajdzińska 51). In the light of the cultural iceberg model, the lexeme kamień constitutes the iceberg's tip, visible in the analysed poem, whereas the underlying, more extensive cultural-linguistic data (with their axiology, i.e. values associated with words) function as the iceberg's base, available to the (interested) reader, willing to make an effort to access it.

Here is the key passage (i.e. the first part of the poem) in the two published English translations:

\section{Conversation with a Stone}

(trans. Stanisław Barańczak, Clare Cavanagh)

I knock at the stone's front door.

"It's only me, let me come in.

I want to enter your insides,

have a look round,

breathe my fill of you."

"Go away," says the stone.

„I'm shut tight.

Even if you break me to pieces,

we'll all still be closed.

You can grind us to sand,

we still won't let you in."

I knock at the stone's front door.

"It's only me, let me come in.

I've come out of pure curiosity.

Only life can quench it.

I mean to stroll through your palace, 
then go calling on a leaf, a drop of water.

I don't have much time.

My mortality should touch you."

„I'm made of stone," says the stone,

„and must therefore keep a straight face.

Go away.

I don't have the muscles to laugh.”

[...]

\section{Conversation with a Rock}

(trans. Joanna Trzeciak)

I knock at the door of the rock.

„It's me, let me in.

I want to enter your interior,

have a look around,

take you in like breath."

„Go away," says the rock,

„I am shut tight.

Even broken to bits

we would be shut tight.

Even ground into sand

we would not let anyone in."

I knock at the door of the rock.

„It's me, let me in.

I come out of sheer curiosity.

Life is my only chance.

I plan on wandering through your palace, and then touring the leaf and the water droplet.

I don't have much time for all this.

My mortality ought to move you."

„I'm a rock," says the rock,

„I can't help but be grave. 
Go away.

I lack the muscles for laughing."

[...]

The English language has two equivalents of Polish kamień: stone and rock; and each of the above translations makes use of a different one. What are the consequences for Szymborska's poem if the lexeme kamień is rendered as stone; and what does it mean if kamien is translated as rock in this text? I believe that a better solution is prompted if we ask the question that is crucial for the poem, namely: in which case is conversation possible? This, in turn, is indicated by the presence or absence of the relevant part of the cultural-linguistic iceberg's base, including the available idioms.

All of the above-mentioned Polish idioms have their exact equivalents in the resources of the English language, and all of them contain the lexeme stone and have negative axiology ${ }^{6}$ :

- milczeć jak kamień = be silent as a stone/grave

- kamienne milczenie = stony silence

- kamień, nie człowiek = he is a stone, not a human being

- mieć serce z kamienia = have a heart of stone

- być z kamienia [about a human being] = be made of stone

Unfortunately, in the case of rock as an equivalent of the Polish word kamień, no such idioms are available. On the other hand, under the entry "rock" English dictionaries list other idioms, whose axiology is not only negative but also positive. The former include hard as rock (referring to very hard physical objects, such as dry bread), to be on the rocks ('to have problems') ${ }^{7}$ and to be caught/stuck between a rock and a hard place (meaning 'to be stuck between two difficult problems'). Among the latter are: he is my rock (about a person who is someone's support; also: "His family was his rock when he was in trouble") or solid as a rock (referring to the firm ground or base of something). These positively valued phrases are rooted in the Bible, where in Psalm 62 it is God that is described as a person's Rock ${ }^{8}$.

6 The lexeme stone and its idioms are analysed in my book (Gicala 116-120, 124-127).

7 The related metaphorical meaning of the adjective rocky is also negative, e.g. a rocky marriage 'a marriage undergoing difficulties'.

8 All meanings of the lexeme rock, including all of these as well as other idioms are described in detail in my book (Gicala 120-127). 
Coming back to the question about the possibility of a conversation in the two translations: a conversation is possible in both cases, but - in the light of lexical data - it will be entirely different. In the case of the unemotional stone, whose connotations are mostly negative (as illustrated by the relevant idioms), the negative outcome of the interaction will probably be less surprising to the English reader than in the case of rock, whose varied axiology, including positive connotations, guides the target reader's expectations towards successful contact with a positively valuated entity.

\section{Conclusions}

To come back to Michael Agar's statement that "[c]ulture becomes visible only when differences appear" (Agar 5), the present study is an attempt at illustrating Agar's thesis by extending it to translation as it is there that cultural-linguistic differences not only come to light but have to find their practical solution. In Wisława Szymborska's poem Rozmowa $z$ kamieniem and its two published English translations, the lexemes kamien - stone - rock may be treated as tips of cultural-linguistic icebergs and, simultaneously, as components of worldviews entrenched in their respective languages. The understanding of Szymborska's text in the original and its rendering into English ought to be supported by the translator's insight into the broader cultural-linguistic foundations that underlie these three lexemes as the poem's keywords. It is these foundations that bring the answer to the key question, asked by the poet, about the possibility and nature of the conversation with kamien (either stone or rock), revealing the chances of success of this conversation.

If an attempt at generalisation may be made, the present study offers a view of texts (especially poetic texts) and their translations as the tips of cultural-linguistic icebergs, between which the translator must skillfully navigate while being aware of what dangers may loom below the surface of words. Hopefully, this framework shows the place where the (human) literary translator still is, and perhaps will always be, irreplaceable.

\section{| References}

Agar, Michael. "Culture: Can you take it anywhere? Invited Lecture Presented at the Gevirtz Graduate School of Education, University of California 
at Santa Barbara." International Journal of Qualitative Methods, 5(2) June 2006. Web. 01.06.2019.

Balbus, Stanisław. Świat ze wszystkich stron świata. O Wisławie Szymborskiej. Kraków: Wydawnictwo Literackie, 1996.

Bartmiński, Jerzy. Aspects of Ethnolinguistics. Transl. Adam Głaz, Ed. Jörg Zinken. London: Equinox Publishing Ltd., 2012[2009].

Brajerska-Mazur, Agata. Filutka z filigranu paraduje w cudzym losie. Wisława Szymborska $w$ anglojęzycznym przekładzie Stanisława Barańczaka i Clare Cavanagh. Lublin: Wydawnictwo KUL, 2012.

Gicala, Agnieszka. Przekładanie obrazu świata. Językowy obraz świata w przekładzie artystycznym. Kraków: Universitas, 2018.

Głaz, Adam, Danaher David S., Łozowski Przemysław, eds. The Linguistic Worldview: Ethnolinguistics, Cognition, and Culture. London: Versita, 2013.

Gralewicz-Wolny, Iwona. Poetka i świat. Studia i szkice o twórczości Wisławy Szymborskiej. Katowice: Wydawnictwo Uniwersytetu Śląskiego, 2014.

Hall, Edward T. The Silent Language. Garden City: Doubleday, 1959.

Katan, David. "Translation as intercultural communication". The Routledge Companion to Translation Studies. Ed. Jeremy Munday. London: Routledge, 2009. Pp. 74-92.

Kopaliński, Władysław. Słownik symboli. Warszawa: Wiedza Powszechna, 1990. Nyczek, Tadeusz. Jarmark cudów. $30 \times$ Szymborska. Warszawa: Państwowy Instytut Wydawniczy, 2015.

Pajdzińska, Anna. “The Linguistic Worldview and Literature”. The Linguistic Worldview: Ethnolinguistics, Cognition, and Culture. Ed. Adam Głaz, David S. Danaher, Przemysław Łozowski (eds.). London: Versita, 2013. Pp. 41-59. Stala, Marian. "Radość czytania Szymborskiej.. Radość czytania Szymborskiej. Wybór tekstów krytycznych, prepared by Stanisław Balbus, Dorota Wojda. Ed. Jerzy Illg. Kraków: Znak, 1996. Pp. 88-110.

Stockwell, Peter. Cognitive Poetics: An Introduction. London: Routledge, 2002. Szymborska, Wisława. Wislawa Szymborska - Odczyt Noblowski 1996. Poeta i Świat, https://tinyurl.com/y88pfxjl, 1996, Web. 4.08.2015.

Szymborska, Wisława. Nic dwa razy. Wybór wierszy / Nothing Twice. Selected Poems. Trans. Stanisław Barańczak and Clare Cavanagh, afterword by Stanisław Barańczak. Kraków: Wydawnictwo Literackie („Seria Dwujęzyczna"), 1997.

Szymborska, Wisława. Miracle Fair. Selected Poems of Wisława Szymborska. Transl. Joanna Trzeciak. New York: W.W. Norton \& Company, 2002[2001]. Wierzbicka, Anna. Understanding Cultures Through Their Key Words. Oxford: Oxford University Press, 1997. 


\section{| Abstrakt}

AgnieszKa Gicala

Tłumaczenia jako góry lodowe, tłumacze jako nawigatorzy

Opierając się na modelu kultury jako góry lodowej, niniejszy artykuł proponuje spojrzenie na tekst poetycki i jego przekłady jako wierzchołki kulturowo-językowych gór lodowych, gdzie zadaniem tłumacza jest nawigacja poprzez meandry języków: źródłowego i docelowego, i zanurzanie się pod powierzchnię słów. Przykładem jest analiza angielskich przekładów wiersza Wisławy Szymborskiej pt. Rozmowa z kamieniem wraz ze słowem-kluczem kamień i jego kulturowo-językową bazą. Narzędziem analizy jest pojęcie językowego obrazu świata. Autorka wyraża nadzieję, że w takim ujęciu czynnik ludzki w przekładzie wciąż jest i zawsze pozostanie niezastąpiony.

Słowa kluczowe: językowy obraz świata, przekład artystyczny, model kultury jako góry lodowej, Wisława Szymborska

\section{| Abstract}

Agnieszka Gicala

Translations as Icebergs, Translators as Navigators: a Poetic Case Study

Following the iceberg model of culture, the present study offers a view of a poetic text and its translations as the tips of cultural-linguistic icebergs. This assigns to the translator the task of navigating the meanders of the source and target languages as well as diving below the surface of words. This thesis is exemplified by an analysis of English translations of Wisława Szymborska's poem Rozmowa z kamieniem with its keyword kamien and its underlying cultural-linguistic foundations, supported by the concept of linguistic worldview. Hopefully, in this framework the human factor in translation still is, and will always be, irreplaceable.

Keywords: linguistic worldview, literary translation, iceberg model of culture, Wisława Szymborska 
| Bio

Agnieszka Gicala - dr hab., anglistka, adiunkt w Katedrze Dydaktyki Przekładu Instytutu Neofilologii Uniwersytetu Pedagogicznego w Krakowie, tłumaczka. Zainteresowania naukowe: językowy obraz świata; językoznawstwo kognitywne, a w nim kognitywna teoria metafory i integracji pojęciowej; zastosowanie tych pojęć w przekładzie; język religii i przekład tekstów religijnych; przekład literacki. Autorka książek Expressing the Inexpressible In Mystical Experience. Conceptual Metaphor and Blending in Translations of 'The Cloud of Unknowing' (2006) i Przekładanie obrazu świata. Językowy obraz świata w przekładzie artystycznym (2018).

Email: agicala@onet.pl

ORCID: 0000-0001-9375-0756 